DOI: 10.12731/2658-4034-2020-2-45-54

\title{
ВЛИЯНИЕ ТИПА ДЕТСКО-РОДИТЕЛЬСКИХ ОТНОШЕНИЙ НА ВОЗНИКНОВЕНИЕ СТРАХОВ В ПРОЦЕССЕ СОЦИАЛИЗАЦИИ ДЕТЕЙ СТАРШЕГО ДОШКОЛЬНОГО ВОЗРАСТА
}

\author{
Кольцова И.В., Долганина В.В.
}

ГБОУ ВО «Ставропольский государственный педагогический институт», г. Ставрополь, Российская Федерация

В статье рассматриваются актуальная для современного общества проблема сочииализаци детей, типь детско-родительских отнотений и страхи детей, которые позволяют прогнозировать позитивную и негативную сочииализащию детей старшего дошкольного возраста. В своей работе авторы описывают влияние детско-родительских отношений на возникновение страхов у детей.

Ключевые слова: сочиализачия; детско-родительские отношения; страхи; дети старшего дошкольного возраста; семья; безопасная социализация; негативная социализация.

\section{INFLUENCE OF THE TYPE OF CHILD-PARENT RELATIONSHIP ON THE OCCURRENCE OF FEARS IN THE PROCESS OF SOCIALIZATION OF CHILDREN OF SENIOR PRESCHOOL AGE}

\section{Koltsova I.V., Dolganina V.V.}

Stavropol State Pedagogical Institute, Stavropol, Russian Federation

The article deals with the problem of socialization of children that is relevant for modern society, types of child-parent relations and fears of children that allow predicting positive and negative socialization of chil- 
dren of senior preschool age. In their work, the authors describe the influence of child-parent relationships on the occurrence of fears in children.

Keywords: Socialization; child-parent relationships; fears; older preschool children; family; safe socialization; negative socialization.

В условиях динамичности социальных процессов, нестабильности общественных систем, объективно возрастают угрозы социального развития личности. Это обстоятельство свидетельствует о необходимости обеспечения безопасности развития личности в процессе социализации.

Социализация - непрерывный многофакторный противоречивый процесс, который продолжается на протяжении всей жизни человека. Наиболее интенсивно он протекает в детском возрасте, когда усваиваются социальные нормы и отношения, формируется мотивация социального поведения, закладываются базовые ценностные ориентации. Процесс социализации происходит во взаимодействии личности с окружающей средой, которая сегодня аккумулирует в себе комплекс опасностей, под влиянием которых дети могут оказаться в ситуации риска [9].

В связи с кардинальными изменениями в жизни общества в последнее время значительно возросла актуальность исследований российских ученых по проблеме детских страхов в процессе социализации. Однако в нашей стране страхи обычно изучаются в узких рамках конкретных, прикладных проблем [3; 4].

Проблема детских страхов находит свое отражение в теоретических исследованиях известных зарубежных и отечественных психологов Ю. Бердниковой [1], Н. Ежкова [5], А.И. Захарова [6], Ю. Климановой [7], Ч. Рикрофт [10], Р. Эмануэль [13] и др.

Изучением влияния детско-родительских отношений на возникновение страхов у старших дошкольников занимались такие ученые-исследователи как: И.И. Вартанова [2], Р.В. Овчарова [8], Е.О. Смирнова [11], Е.Ю. Фирсова [12] и др.

Считается, что характер детско-родительских отношений, возникающих в семье и во многом определяющих эмоциональное бла- 
гополучие ребенка, играет важную роль в возникновении страхов у детей. Для психического состояния детей очень важно чувствует ли ребенок любовь со стороны родителей, значимы ли они для ребенка, как дети относятся к своим родителям.

Отношение родителей к детям является важным фактором психосоциального развития ребенка в процессе социализации. Ребенок усваивает нравственные позиции родителей, их отношение к окружающим людям, оценки и суждения, предрасположен к внушению ближайшего окружения, удовлетворяет свою потребность в положительных эмоциях. Специфика взаимоотношений между детьми и родителями находит свое отражение в поведении самих родителей и является образцом или моделью для построения отношений с другими людьми. Практически нет такого психологического или социального аспекта поведения ребенка, который не находится в прямой зависимости от семейных условий и отношений.

Большинство авторов влияние внутрисемейных детско-родительских отношений на становление личности ребёнка определяют, как основной фактор, любое значительное отклонение от норм может означать некую ущербность, а, часто, и кризис в данной семье, в ее воспитательных возможностях.

Основываясь на данные литературных источников, мы предположили, что на возникновение страхов у детей в возрасте 6-7 лет в процессе социализации может влиять ситуация в семье, отношение к ним родителей, а также стиль семейного воспитания.

Исследование проводилось на базе Муниципального дошкольного образовательного учреждения д/с №20 г. Ставрополя. Выборка составила 21 ребенок старшего дошкольного возраста. В исследовании приняли участие 7 детей из многодетных семей, 6 детей являются единственным ребенком в семье, 8 испытуемых из двухдетной семьи.

В качестве цели исследования нами было обозначено изучение влияния детско-родительских отношений на возникновение страхов у детей старшего дошкольного возраста в процессе социализации.

В соответствии с целью исследования нами были подобраны и апробированы диагностические методики: 
- опросник детско-родительских отношений (А.Я. Варга и В.В. Столин);

- методика «Рисунок семьи» (Т. Г. Хоментаускас);

- тест тревожности (Р. Тэммл, М. Дорки, В. Амен);

- Методика «Страхи в домиках» (А.И. Захаров и М. Панфилова).

В результате исследования были выделены типы детско-родительских отношений в семьях старших дошкольников, участвующих в эксперименте:

«Принятие-отвержение»: родители принимают своего ребенка (6 семей - 29\%). Они любят ребенка таким, какой он есть, уважают его личность, проявляют к нему сочувствие, одобряют его планы и интересы.

«Авторитарная гиперсоциализация»: опрошенные родители (5 семей $-24 \%$ ) характеризуются авторитарным стилем воспитания: строгой дисциплиной, безусловным послушанием; навязывают свою точку зрения. Они внимательно следят за социальными достижениями ребенка, его привычками, чувствами и мыслями.

«Маленький неудачник»: родители из 3 семей (14\%) считают своего ребенка младше своего реального возраста и приписывают ему личную и социальную несостоятельность. Интересы, увлечения, мысли и чувства ребенка не воспринимают всерьез. Ребенок кажется родителям не приспособленным, открытым к дурным влияниям. Возможно, именно поэтому 40\% матерей предпочитают строго контролировать своих детей.

«Симбиоз»: родители из 3 семей (14\%) испытуемых отмечают, что они едины с ребенком, стремятся удовлетворить все потребности ребенка, защитить его от трудностей и неприятностей жизни. Они постоянно испытывают тревогу за ребенка, считают его маленьким и беззащитным. Это может быть связано с малым возрастом детей, а также может быть связано с повышенной личностной тревожностью самих родителей.

«Кооперация»: опрошенные родители (4 семьи - 19\%)интересуются делами и планами ребенка, стараются помочь ему, высоко ценят творческие и интеллектуальные способности ребенка, испытывают чувство гордости за его достижения (например, спорт). 
Рассмотрим результаты проведения теста «Рисунок семьи» (Т.Г. Хоментаускас). В группе испытуемых преобладают следующие симптомокомплексы, характеризующие детско-родительские отношения в семье: 7 детей (33\%) находятся в благоприятной семейной ситуации; 6 испытуемых (29\%) - отмечают враждебность в семейной ситуации и чувство тревоги; для 5 дошкольников $(24 \%)$ характерна тревожность; у 3 респондентов (14\%) - выявлено чувство неполноценности в семейной ситуации; тревожность.

Можно отметить, что в семьях испытуемых, где в ходе исследования были диагностированы неблагоприятные типы детско-родительских отношений, такие как «отвержение», «авторитарная гиперсоциализация», «маленький неудачник», дети в своих рисунках отмечали враждебность в семейной ситуации, тревожность, чувство неполноценности в семейной ситуации, что является предпосылкой к негативной социализации испытуемых дошкольного возраста.

Рассмотрим результаты, полученные с помощью теста Р. Тэммл, М. Дорки, В. Амен (ИТ): высокий уровень выявлен у 8 испытуемых (38\%); средний уровень характерен для 6 респондентов (29\%); низкий уровень диагностирован у 7 дошкольников (33\%);

Диагностическое обследование с помощью методики шкала явной тревожности CMAS позволило выявить, что: 2 испытуемым (9\%) не свойственна тревожность; у 5 человек (24\%) выявлен нормальный уровень тревожности; для 6 детей (29\%) характерен несколько повышенный уровень; у 5 человек (24\%) диагностирован явно повышенный уровень тревожности; очень высокий уровень тревожности выявлен у 3 человек (14\%).

Таким образом, у старших дошкольников в результате диагностики было выявлено: 14 человек (67\%) - медицинские страхи; 9 человек (43\%) - страх смерти; 9 человек (43\%) - страхи социальные, 5 человек (24\%) - страх физического ущерба; 4 человек (19\%) - страх животных; 3 человека (14\%) - страх сказочных персонажей; 3 человека (14\%) - пространственные страхи; 2 человека (9\%) - страх темноты.

Соотнесение полученных результатов по диагностике детскородительских отношений с данными по методикам диагностики страхов, позволило выявить, что те старшие дошкольники, в семьях 
которых отмечены неблагоприятные типы детско-родительских отношений, имеют явные проявления страхов, а именно:

- высокие баллы «принятие-отвержение» ребенка, т.е. эмоционально отрицательное (отвержение) отношение в семье. Неприятие матерью порождает у ребенка множество страхов, в том числе страх перед жизнью. Ребенок рано осознает свою ненужность, что его никто не любит, не сможет полюбить и, со временем, это может сделаться его внутренним убеждением. Такие дети вырастают жестокими и агрессивными или становятся несчастными людьми, ощущая себя нелюбимыми и ни на что не способными. Также были диагностированы медицинские (заболеть, заразиться, врачей, крови, уколов, боли и др.) и социальные виды страхов (полицейских, чужих людей, огня, пожара и пр.). У этих детей отмечается враждебность в семейной ситуации. Диагностика проявлений тревожности показала наличие у них среднего, высокого и очень высокого уровня тревожности.

- при «авторитарной гиперсоциализациии» отчетливо просматривается авторитаризм и возможность наказания за проступки. Требования взрослых нередко приводят ребенка к тому, что он начинает испытывать страх не соответствовать ожиданиям окружающих, наказания, страх сделать что-нибудь не так не то, осуждения, «быть не тем», диагностированы также медицинские страхи и страх физического ущерба. У таких детей наблюдается низкая самооценка, зависимость от чужого мнения. Со временем он привыкает «опускать руки», сдаваться без борьбы, даже в обычных ситуациях, или же постоянно бороться за право быть значимым, доказывать свою состоятельность. Если ребенок начинает понимать, что родители могут любить его только за что-то: за успехи, похвалу окружающих, что сам по себе он никакой ценности не представляет, у него возникает неуверенность, самоотрицание, пессимистическое отношение к жизни. Для такого ребенка так же характерны болезненная стеснительность, он не решается проявлять себя. Ведущим симптомокомплексом по методике «Рисунок семьи» у этих детей является тревожность. Диагностика проявлений тревожности показала наличие у них среднего, высокого и очень высокого уровня тревожности. 
«Маленький неудачник»- родители стремятся инфантилизировать ребенка, приписать ему личную и социальную несостоятельность. Как следствие ребенка начинают тревожить вопросы о здоровье (медицинские страхи), смерти, страх сказочных персонажей, появляется страх одиночества (социальные страхи), потери близких и значимых людей, ощущение слабости и неуверенности в себе. У таких детей возникают проблемы при контактах со сверстниками. Следует отметить, что у ребенка формируется такая условно-рефлекторная реакция как «выученная беспомощность» - восприятие любых препятствий как непреодолимых. Ребенок перекладывает свою ответственность на родителей, да и родители сами готовы взять ее на себя. Для детей характерно чувство неполноценности в семейной ситуации. Диагностика проявлений тревожности показала наличие у них среднего, высокого и явно повышенного уровня тревожности.

«Симбиоз»- по результатам исследования характеризуются детско-родительскими симбиотическими связями. Выявлен страх потери близких, а также страх смерти. Дети отмечают благоприятную семейную ситуацию, для них характерен низкий уровень тревожности.

«Кооперащия»- предусматривающая сотрудничество взрослого с ребенком. У данных детей ведущим симптомокомплексом по методике «Рисунок семьи» отмечена благоприятная семейная ситуация. Кроме того, диагностика проявлений тревожности показала наличие низкого, нормального уровня или тревожность не свойственна. Такой тип детско-родительских отношений позволил диагностировать возрастные страхи: страх темноты, страх животных и др.

Таким образом, проведя диагностическое исследование детей старшего дошкольного возраста на предмет выявления преобладающего типа детско-родительских отношений, мы смогли их соотнести с видами страхов, тем самым решив поставленные в нашем исследовании задачи.

\section{Выводы}

Тип детско-родительских отношений является важным фактором в социализации детей старшего дошкольного возраста: 
- благоприятное отношение родителей к детям, характеризующееся эмоциональным принятием и кооперативными формами взаимодействия, способствует формированию «архаических», «магических», «социальных страхов у детей, и как следствие, свидетельствует об успешной социализации старших дошкольников;

- «витальные» и «школьные» страхи формируется под влиянием негативных форм детско-родительских отношений (симбиоз, гиперсоциализация, отвержение, маленький неудачник) и выступают фактором негативной социализации детей.

Проранжировав доминирующие виды страхов, было выявлено, что на первом месте у детей старшего дошкольного возраста стоят медицинские страхи; на втором страх смерти; на третьем страх сказочных персонажей, страх животных, пространственные страхи; на четвертом страх физического ущерба; на пятом страх темноты и страхи социальные.

Порядок рождения ребенка в семье является детерминантной в формировании страхов и детско-родительских отношений:

- старший ребенок в семье испытывает больше по количеству страхов, чем младшие сиблинги.

- родители много ожидают от своих первенцев и относятся к ним с нежностью, но и наказывают их строже. С более поздними детьми родители ведут себя спокойнее и их ожидания более реалистичны.

В наибольшей степени страхам подвержены единственные дети в семье как эпицентр родительских забот и тревог.

\section{Список литературы}

1. Бердникова Ю. Мир ребенка. Развитие психики, страхи, социальная адаптация, интерпретация детского рисунка. СПб.: Наука и Техника, 2007. 288 с.

2. Вартанова И.И. Мотивация учебной деятельности и особенности детско-родительских отношений // Психология обучения. 2005. N 9. С. 5-7. 
3. Долганина В.В., Кольцова И.В., Волосникова Т.А. Исследование эффективности психолого-педагогических средств преодоления страхов у младших школьников, возникающих в учебном процессе: прикладной аспект // Мир науки. Педагогика и психология. 2019. Т. 7. № 5. С. 50.

4. Долганина В.В., Кольцова И.В., Ширванян А.Э. Психолого-педагогические средства преодоления страхов у младших школьников, во3никающих в учебном процессе // Научный потенциал. 2019. № 4 (27). C. $37-40$.

5. Ежкова Н. Развитие эмоций в совместной с педагогом деятельности // Дошкольное воспитание. 2003. №1. С. 20-27.

6. Захаров А.И. Дневные и ночные страхи у детей. СПб.: Речь, 2010. $310 \mathrm{c}$.

7. Климанова Ю. Нарисуй свой страх: Детские страхи // Семья и школа. 1999. № 9. С. 22-24.

8. Овчарова Р.В. Психология родительства: учеб. пособие для студентов вузов, обучающихся по направлению и специальностям психологии. М.: Academia, 2005. 368 c.

9. Першина Т.В. Формирование социальной компетентности детей и учащейся молодежи как фактор безопасной социализации // Вестник Череповецкого университета. 2012. №2 (25). С. 21-24.

10.Рикрофт Ч. Тревога и неврозы / Пер. с англ. В.М. Астапов, Ю.М. Кузнецова / Под ред. В.М. Астапова. М.: ПЕР СЭ, 2008. 142 с.

11. Смирнова Е.О. Структура и динамика родительского отношения в онтогенезе ребенка // Вопросы психологии. 2007. N 2. С. 57-67.

12. Фирсова Е.Ю. Особенности детско-родительских отношений в семьях умственно отсталых школьников // Специальная психология. 2009. N 3. C. 53-59.

13. Эмануэль Р. Страх. М.: Проспект, 2002. 79 с.

\section{References}

1. Berdnikova Yu. Mir rebenka. Razvitie psikhiki, strakhi, sotsial'naya adaptatsiya, interpretatsiya detskogo risunka. SPb.: Nauka i Tekhnika, 2007. $288 \mathrm{~s}$. 
2. Vartanova I.I. Motivatsiya uchebnoy deyatel'nosti i osobennosti detsko-roditel'skikh otnosheniy // Psikhologiya obucheniya. 2005. N 9. S. 5-7.

3. Dolganina V.V., Kol'tsova I.V., Volosnikova T.A. Issledovanie effektivnosti psikhologo-pedagogicheskikh sredstv preodoleniya strakhov u mladshikh shkol'nikov, voznikayushchikh v uchebnom protsesse: prikladnoy aspekt // Mir nauki. Pedagogika i psikhologiya. 2019. T. 7. № 5. S. 50

4. Dolganina V.V., Kol'tsova I.V., Shirvanyan A.E. Psikhologo-pedagogicheskie sredstva preodoleniya strakhov u mladshikh shkol'nikov, voznikayushchikh v uchebnom protsesse // Nauchnyy potentsial. 2019. № 4 (27). S. 37-40.

5. Ezhkova N. Razvitie emotsiy v sovmestnoy s pedagogom deyatel'nosti // Doshkol'noe vospitanie. 2003. №1. S. 20-27.

6. Zakharov A.I. Dnevnye i nochnye strakhi u detey. SPb.: Rech', 2010. $310 \mathrm{~s}$.

7. Klimanova Yu. Narisuy svoy strakh: Detskie strakhi // Sem'ya i shkola. 1999. № 9. S. 22-24.

8. Ovcharova R.V. Psikhologiya roditel'stva: ucheb. posobie dlya studentov vuzov, obuchayushchikhsya po napravleniyu i spetsial'nostyam psikhologii. M.: Academia, 2005. 368 s.

9. Pershina T.V. Formirovanie sotsial'noy kompetentnosti detey i uchashcheysya molodezhi kak faktor bezopasnoy sotsializatsii // Vestnik Cherepovetskogo universiteta. 2012. №2 (25). S. 21-24.

10. Rikroft Ch. Trevoga i nevrozy / Per. s angl. V.M. Astapov, Yu.M. Kuznetsova / Pod red. V.M. Astapova. M.: PER SE, 2008. 142 s.

11. Smirnova E.O. Struktura i dinamika roditel'skogo otnosheniya v ontogeneze rebenka // Voprosy psikhologii. 2007. N 2. S. 57-67.

12. Firsova E.Yu. Osobennosti detsko-roditel'skikh otnosheniy v sem'yakh umstvenno otstalykh shkol'nikov // Spetsial'naya psikhologiya. 2009. N 3. S. 53-59.

13.Emanuel' R. Strakh. M.: Prospekt, 2002. 79 s. 